\title{
Juridical Analysis of the Decision of the Constitutional Court Number: 69 / PUU- XIII / 2015 on Article 29 Law Number 1 of 1974 Concerning Marriage
}

\author{
Yusri; Yaswirman; Neneng Oktarina \\ Notary Masters Program, Faculty of Law, Andalas University, Indonesia
}

http://dx.doi.org/10.18415/ijmmu.v6i5.1162

\begin{abstract}
Indonesia as a legal state, the presence of law in a country aims to guarantee life to protect the interests of citizens. In the Indonesian government system there are several branches of power, namely the legislative, executive and judiciary branches, the judicial power branches are the Supreme Court and the Constitutional Court. The Constitutional Court's authority is contained in Article $24 \mathrm{C}$ paragraph (1) and (2) adjudicating at the first and last level whose decision is final to review the Law on the Constitution. Marriage agreement is a form of agreement that regulates assets in marriage and others. A marriage agreement is also an agreement which can affect other regulations. So with the regulation of the marriage agreement in Article 29 paragraph (1) prior to the lawsuit for judicial review to the Constitutional Court stating that the marriage agreement was made at the time, and before the marriage took place, this is what prevents many married couples from different citizens who previously were not have a marriage agreement while their interests require a marriage agreement. The decision analysis can be concluded that the Urgency of the marriage agreement in its decision No.69 / PUU-XIII / 2015 states that the importance of the marriage agreement is related to the position of shared property so that there is a separation of husband's assets with the wife's assets both regarding their respective belongings and the assets that belong to each other obtained during the marriage known as joint property. Whereas the assets obtained before their marriage period together are known as inheritance or personal property obtained after the marriage period which is usually referred to as acquisition assets. Due to the legal marriage agreement before MK Decision Number 69 / PUU-XIII / 2015, Indonesian citizens who carry out marriages mixed and does not make a marriage agreement, the Indonesian citizen may not have immovable property in the form of ownership or building rights.
\end{abstract}

Keywords: Marriage Agreement; Joint Assets; Decision Analysis 


\section{Introduction}

Indonesia is a state of law ${ }^{1}$. The presence of law in a country aims to make life more peaceful ${ }^{2}$, protect every interest by forming a life regulation accompanied by sanctions that are binding and force ${ }^{3}$, uphold justice ${ }^{4}$. The state has regulated the constitutional rights of each of its citizens through the 1945 Constitution which is in line with those inherent in the nature and existence of every human being as a creature of God Almighty and is a gift that must be respected, upheld and protected by the rule of law, government, and everyone, for the sake of honor and protection and human dignity ${ }^{5}$.

Citizens are one of the essential elements and basic elements of a country. Citizenship status creates a reciprocal relationship between citizens and their countries. Every citizen has rights and obligations towards his country. Conversely, the State has an obligation to provide protection for its citizens.

One of the constitutional rights of Indonesian citizens is the right to take legal action in opposing or accusing the State's decisions which are considered to be detrimental to the constitutional rights of the citizens of the country concerned ${ }^{6}$. The legal remedies can be carried out on State administrative decisions (beschikkingsdaad van de administratie), regulatory decisions (regelensdaad van staat organ), both material and formal, by conducting substantive judical review (materaile toestsing) or procedural judical review (formal toestsing), or formal against the judge's decision (vonis) by submitting it to a higher court institution, namely the Appellate, Cassation or Judicial Review level ${ }^{7}$.

Within the Indonesian system of government the branches of power are divided into branches of legislative, executive and judicial power. Branches of legistative power are found in the People's Consultative Assembly (MPR), the People's Representative Council (DPR), and the Regional Representative Council (DPD), while the branches of judicial power are the Supreme Court (MA) and the Constitutional Court (MK). Meanwhile, the presidential institution and the ranks of government to the lowest level belong to the executive branch of power.

Before the amendment to the 1945 Constitution, the function of the judiciary only consisted of the Supreme Court as the exercise of judicial power which was independent, meaning that the judiciary must not be influenced by other branches of power, especially the government.

The authority of the Constitutional Court in testing the law is not only binding on the applicant but also binding on the Constitutional Court itself. The MK's function as a norm maker or positive legislator is actually a function of the legislative body. Based on the authority of the Constitutional Court as contained in Article 24C of the 1945 Constitution to examine the Law on the 1945 Constitution the Constitutional Court has the authority: among other things the Constitutional Court has the authority to adjudicate at the first and last level whose decisions are final to test the Law on the Constitution, dispute decision the authority of state institutions its authority is given by the Constitution, decides the dissolution of political parties, and decides on disputes over the results of general elections; and the Constitutional Court is obliged to give a decision on the opinion of the House of Representatives regarding alleged violations by the President and / or Vice President according to the Basic Law. One of them tested Law number 1 of 1974 concerning Marriage Article 29 concerning Marriage Agreement against the 1945 Constitution.

\footnotetext{
${ }^{1}$ Republic of Indonesia, 1945 Constitution, Chapter I, Article 1 Paragraph (3)

${ }^{2}$ Mochtar Kusumaatmadja, Konsep-Konsep Hukum dalam Pembangunan, (Bandung: PT. Alumni, 2006), p. 3.

${ }^{3}$ Sudikno Mertokusumo, Bunga Rampai Ilmu Hukum, (Yogyakarta: Liberty, 1984), p.1.

${ }^{4}$ Suryadi MP, Ilmu Budaya Dasar, (Jakarta: universitas Terbuka, 1985), p.3.

${ }^{5}$ Jimly Asshiddiqie, www.jimly.com/makalah/HAK_KONSTITUSIONAL PEREMPUAN.doc, downloaded 09 April 2017.

${ }^{6}$ D.Y. Witanto. Hukum Keluaraga Hak dan Kedudukan Anak Luar kawin. (Jakarta:Prestasi Pustaka), p. 232.

${ }^{7}$ Ibid.
} 
Marriage is an inner and outer bond between a man and a woman as husband and wife that aims to form a happy and eternal family or household based on the divinity of the Almighty ${ }^{8}$.

After the entry into force of Law Number 1 of 1974 concerning the separation of shared assets as stipulated in the provisions of article 35 paragraph (1) it is stated that the assets obtained during marriage become joint assets and paragraph (2) each property from the husband or wife and property that is each gift or inheritance is obtained insofar as no marriage agreement is held, then mastery is under their respective control ${ }^{9}$.

Marriage agreements or often referred to as prenuptial agreements in Law Number 1 of 1974 Article 29 states "that at the time before the marriage takes place both parties on a joint purpose may submit a written agreement that is ratified by the marriage registrar, after which the contents also apply to the parties the third is stuck".

Based on the description above, the author decides to raise the issue entitled "Judicial Analysis of the Constitutional Court Decision Number 69 / PUU-XIII / 2015 Against Article 29 of Law Number 1 of 1974 concerning Marriage".

\section{Formulation of the Problem}

Based on the above background the writer wants to formulate the problem as follows:

1. What is the urgency of the marriage agreement and its relation to joint property in the marriage?

2. What are the legal consequences of marital assets before and after the Constitutional Court Decision Number 69 / PUU-XII / 2015 concerning Marriage Agreements?

\section{Discussion}

\section{The Urgency of Marriage Agreements and their Relationship to Joint Treasures in Marriage.}

Marriage agreements are usually made for the benefit of legal protection of each person's property, husband or wife, although the law does not regulate the purpose of the marriage agreement and what can be promised, everything is left to both parties ${ }^{10}$.

According to Herlien Budiono, when dealing with an agreement, it must be ensured that the legal actions meet at least four elements in the agreement. After ensuring that a legal action is an agreement, the next step is to check the validity of the agreement is valid or not the agreement can be ascertained by testing it against 4 (four) conditions for the validity of an agreement as stipulated in Article 1320 of the Civil Code, namely ${ }^{11}$ :

\footnotetext{
${ }^{8}$ Munir Fuady, Konsep Hukum Perdata, (Jakarta:PT.Raja Grafindo Persada), p. 18.

${ }^{9}$ Ibid, hlm.21.

${ }^{10}$ Journal dunia-ibu.org online,Perjanjian Pranikah,copyright 2001-2002 dalam http://www.duniaibu.org/html/ perjanjian_pra_nikah.html), accessed April 2, 2018.

${ }^{11}$ Herlien Budiono, Op.Cit, p. 73.
} 
1. Agree those who remind themselves

The agreement in question is the existence of conformity between the parties who made an agreement. In making the agreement, the parties have the free will to pour what will be made in the agreement.

2. The ability to make an engagement

Ability means, the ability for someone who according to the law has been considered an adult and deserves to do a legal act. The parties can carry out a legal action because in accordance with the laws and regulations they are declared to have been mature and capable of law. The legal action referred to in this case is to make a marriage agreement.

3. A certain thing

In making an agreement, it must contain a certain matter. The parties who want and have made an agreement, in this case making a marriage agreement, must pay attention to what matters can be stated in the agreement, so that with the agreement can provide protection for the parties who made it.

4. A lawful cause

Marriage agreements made by both parties must be based on appropriate reasons, and do not conflict with public order, law, religion and morality in society.

That wealth in a marriage is the most important thing in a marriage. Wealth in marriage can make a happy family but also wealth can cause havoc for the family. Be happy when the family lives in harmony, but if there is a commotion even to the point of divorce the property can be disastrous among them (husband and wife). With that a marriage agreement, assets in a marriage are the main objects in the marriage agreement ${ }^{12}$.

That the purpose of making a marriage agreement is ${ }^{13}$ :

1. Separating assets between husband and wife so that their assets do not mix. Therefore, if one day they divorce, each party's assets are protected, there is no struggle over shared assets or gono-gini (in Javanese);

2. For the debts of each party they make in their marriage, each will be individually responsible;

3. If one of the parties sells their assets, they do not need to ask permission from their spouse (husband / wife) in advance;

4. Likewise with the credit facilities that they propose, they no longer have to ask permission in advance from their spouse (husband / wife) in terms of guaranteeing the assets registered in the name of one of them.

Based on this, the Constitutional Court is of the view that a marriage agreement is an agreement in general. Making agreements is based on the following principles ${ }^{14}$ :

\footnotetext{
${ }^{12}$ Sriono, Perjanjian Kawin Sebagai Bentuk Perlindungan Terhadap Harta Kekayaan Dalam Perkawinan, Jurnal Ilmiah Advokasi, Volume 4 Nomor 2, September 2016, p. 73

${ }^{13}$ Op Cit, MK Decision Number 46/PUUXIII/2015
} 
1. The principle of freedom of contract that is to make any kind of engagement as long as it does not conflict with the Law, Decency and Public Order regulated in Article 1337 of the Civil Registry;

2. The principle of consensualism, which is based on an agreement between the parties, Article 1320 of the Civil Code;

3. The principle of binding power, namely the principle of pacta suntservanda, namely binding power, such as the law;

4. The principle of personality, namely to determine personnel in the agreement as a source of engagement;

5. The principle of trust or vortrouwensabbeginsel means someone who enters into an agreement and creates an engagement with another person, between the parties there is a belief that will fulfill each other's achievements;

6. The principle of good faith or goeder trouw, namely in carrying out the engagement based on good faith.

Based on the decision of the Constitutional Court submitted by Mrs. Ike Farida which granted part of Article 29 paragraphs (1), (3) and (4) had made changes in the Marriage Law especially in the case of the marriage agreement, so the contents of Article 29 of Law No. 1 In 1974 concerning Marriage in terms of the marriage agreement became:

1. At the time, before it is held or during marriage, both parties with mutual agreement can submit a written agreement that is ratified by the marriage registrar or notary, after which the contents also apply to third parties as long as the third party is involved;

2. The agreement cannot be ratified if it violates the boundaries of law, religion and glory;

3. The agreement is valid since the marriage takes place unless specified otherwise in the marriage agreement;

4. During the marriage, the marriage agreement can be regarding marriage assets or other agreements, can not be changed or revoked, unless both parties have an agreement to change or revoke, and the change or revocation does not harm a third party.

Since the decision of the constitutional court and recorded in the state news on the marriage agreement can be made or submitted a marriage agreement that is not only after or before the marriage takes place but during the marriage takes place. The marriage agreement based on paragraph (4), is related to the marriage assets and also other agreements outside the marriage property that can be promised.

Concerning the validity of the marriage agreement, that the agreement made during the marriage starts the marriage takes place or in other words that the property before the marriage agreement also

\footnotetext{
${ }^{14}$ Sudikno Mertokusumo, 1988, Hukum Acara Perdata di Indonesia, Liberty, Yogyakarta, p. 97
} 
participates in the marriage agreement made during the marriage. To provide legal protection for one party (husband / wife) for marriage assets that existed before the marriage agreement was made, giving an opportunity not to be promised because of the phrase in the decision stating that the marriage agreement is valid since the marriage unless otherwise stipulated in the marriage agreement .

The exception is the one that provides the opportunity or protection that assets or others that existed before the marriage agreement are made are not included in the marriage agreement. So that the marriage agreement began to take effect based on the agreement of both parties. Likewise, the existence of the ruling of this constitutional court provides protection for Indonesian citizens who are married to foreigners relating to marital property. As stated in Article 35 of Law No. 1 of 1974 concerning Marriage that assets in a marriage are distinguished between inherited and shared assets ${ }^{15}$.

Likewise, as the petitioner's application relates to Article 21 and Article 36 UU Number 5 of 1960 concerning the UUPA, with the existence of a decision regarding a marriage agreement that can be made during a marriage, the articles are based on the judge's consideration that it is groundless because it meets the element of nationality. Likewise, a marriage agreement that provides opportunities for the regulation of assets can provide protection for Indonesian citizens who are married to foreigners in terms of assets.

With this decision also provides fresh air for married couples especially citizens of different nationality couples who want to make a marriage agreement but because it is obstructed by the provisions of the legislation it can not do it. Because the couple just realized the importance of the marriage agreement to provide protection for wealth in marriage. The marriage agreement must be made in writing and validated by the marriage registrar, but if the marriage agreement is made before a notary then the marriage agreement does not need to be ratified by the marriage registrar, this will make it easier to hold a marriage agreement.

Juridical analysis of the urgency of a marriage agreement in a marriage of shared property so that there is a legal certainty of the good property of the husband / wife both regarding their respective belongings and the assets obtained during the marriage in our marriage to recognize shared property. If the marriage takes place between fellow Indonesian citizens not implementing a marriage agreement regarding his property regulated in Article 35 of Law No. 1 of 1974 concerning Marriage if a marriage breaks up both death and divorce in the case of distribution of assets, it becomes difficult because there is no separation of assets belonging to assets together, luggage and gift or inheritance. Conversely, if a marriage agreement is made the marriage agreement is easier than the completion of the distribution of assets than not making a marriage agreement because of the classification of shared assets, gift assets or inheritance.

This will become a complicated problem when an Indonesian citizen with a foreign citizen without entering into a marriage agreement in advance and feels more unfair when they will own a house of ownership rights and building rights will stumble on Article 21 paragraph 3 of the Basic Agrarian Law. Foreigners who apply this law obtain property rights due to inheritance without a will or mixing of assets due to marriage, likewise Indonesian citizens who have ownership rights after the enactment of this law lose citizenship must waive that right within 1 year from the acquisition of the right or loss of citizenship. If after that period of time the ownership rights are not released, the rights will be voided because the law and land fall on the state provided that the rights of other parties that burden them continue ${ }^{16}$ and Article 36 that Indonesian citizens who can have building rights and more ironically when the perpetrators mixed marriages must reduce property rights and building rights to usage rights because there is no separation of their property in marriage.

\footnotetext{
${ }^{15}$ Article 35 UU Number 1 of 1974 concerning Perkawinan

${ }^{16}$ UUPA Article 21 paragraph 3 of 1960
} 
Joint assets in a marriage are property in a marriage that is produced by a married couple together during the marriage period. What is not included in the category of joint assets are assets obtained or produced before their marriage, usually referred to as inheritance personal property obtained after the marriage period which is usually called acquisition (grant assets, gifts, and alms).

Various types of joint assets according to Article 35 of Law Number 1 of 1974 concerning Marriage in full reads as follows:

1. Property obtained during marriage becomes shared property.

2. The inheritance of each as a gift or inheritance is under the control of each other as long as the parties do not specify otherwise.

According to Sayuti Thalib, husband and wife's wealth can be classified into several types as follows ${ }^{17}$ : Seen from the point of origin, husband and wife's wealth can be classified into three groups, namely:

a. Inborn property, that is, the property of each husband and wife that they had before they married either came from their own inheritance, grants or businesses;

b. Assets of each husband and wife obtained after marriage, that is obtained from inheritance, grants, or will for each husband or wife and not obtained from their business, individually or together;

c. Livelihood assets, which are assets that a husband and wife can obtain after they are in a marital relationship by their own business, individually or jointly.

a) In Islam Law Complications (KHI) Article 85 regarding Joint Assets in Marriage states that "the existence of joint property in a marriage does not rule out the existence of property belonging to each husband or wife". The regulation of joint assets in KHI Article 85 further states:

a. Husband's inheritance, that is, property that the husband brings since before marriage

b. The wife's inborn property, that is, the property she has been carrying since before marriage.

c. Assets with a husband and wife, i.e. property obtained during marriage becomes joint property with a husband and wife

d. Assets from gifts, grants, inheritance, and husband's shadaqah, i.e. assets that he obtained as gifts or inheritance.

b) According to customary law regarding joint property in a marriage is all property held by a husband and wife as long as they are bound in a marriage bond, both personal assets originating from inheritance, grant assets, own income assets, livelihood assets shared by husband and wife and goods gift items. In its position as capital of wealth to finance the life of a married couple, the marriage assets can be classified into several types, namely:

\footnotetext{
${ }^{17}$ Sayuti Thalib, 1996, Hukum Keluarga Indonesia, Jakarta: Universitas Indonesia, p.83.
} 
1. Assets obtained by a husband or wife before marriage, namely inherited assets;

2. Assets obtained by an individual husband or wife before or after marriage, namely income assets;

3. The assets obtained by husband and wife together during marriage are livelihood assets.

4. Treasures obtained by a husband and wife together at a wedding ceremony as a gift we call a wedding gift.

c) Civil Code regarding joint assets in a marriage, Article 119 of the Civil Code stipulates that, from the moment the marriage takes place, the law applies unanimously between husband and wife wealth, only regarding that with the marriage agreement not held with other provisions. The unity of property during the marriage is carried out and may not be nullified or changed with an agreement between any husband and wife. If you intend to deviate from this provision, the husband and wife must travel the marriage agreement stipulated in Article 139 through Article 154 of the Civil Code. Article 128 through Article 129 of the Civil Code stipulates that if a marriage is broken between a husband and wife, the joint assets shall be divided between the husband and wife without regard to the party from whom the assets were previously obtained. Concerning the marriage agreement is justified by the legislation as long as it does not violate the moral code and public order that prevails in people's lives. As for the assets that become husband or wife are (1) inherited assets, i.e. assets that existed before their marriage, (2) assets obtained each during the marriage but are limited to the acquisition of gifts, grants, and inheritance. Beyond this type all assets go directly into joint property in marriage. All assets obtained by a husband and wife during marriage are joint property, both assets are obtained separately or jointly obtained. Likewise, the assets purchased during the marriage bond are shared property, it does not matter whether the wife or husband buys, it does not matter whether the wife or husband knows at the time of the purchase or also does not matter on whose behalf the property is registered.

\section{Legal Consequences for Marriage Assets Before and After MK Decision Number 69 / PUU / 2015 Regarding Marriage Agreements}

The presence of the Constitutional Court Decision Number 69 / PUU-XIII / 2015 at least brings a breath of fresh air for married couples who engage in mixed marriages, while the couple at the time of marriage have not yet made a marriage agreement that regulates the assets obtained during the marriage.

The Constitutional Court's ruling provides an interpretation of Article 29 of the Marriage Law, namely that a husband and wife couple may be able to rearrange their property throughout the marriage. MK Decision Number 69 / PUU-XIII / 2015 at least gives concessions to married couples to be able to regulate their wealth in a marriage agreement throughout their marriage, so that changes occur related to the making of a marriage agreement.

It is necessary to understand the provisions governing assets in a marriage, that is, assets in a marriage regulated in Article 35 of the Marriage Law are first: assets obtained during marriage become joint assets, which is meant by joint assets i.e. all assets obtained during marriage . Second: property; the inheritance of each husband and the assets obtained from each gift or inheritance are under each supervision, as long as the parties do not specify otherwise, the intention is that the assets carried by each husband and wife as well as property obtained respectively from gifts / inheritance is under their respective control, as long as the parties do not specify otherwise. So if the marriage is not made a marriage agreement that regulates the property obtained during the marriage, the property obtained during 
the marriage becomes joint property (gono-gini). However, if a husband and wife will make a marriage agreement governing his property, then under Article 29 of the Marriage Law that a marriage agreement must be made before or when the marriage takes place, with a written agreement.

During the marriage, the marriage agreement cannot be changed, except if from both parties there is an agreement to change, and the change does not harm a third party.

Then after the issuance of the Constitutional Court's ruling, the provisions of Article 29 paragraph (1) of the Marriage Law in conjunction with the Constitutional Court Decree Number 69 / PUU-XIII / 2015, that marriage agreements can be made before or during the marriage, can also be made after or during the marriage bond, with mutual agreement, a marriage agreement can be filed in writing which is ratified by a marriage registrar or notary whose contents may apply to third parties as long as the third party is involved. The Constitutional Court's decision related to Article 29 paragraph (3) of the Marriage Law which regulates the entry into force of the marriage agreement can come into force since the marriage takes place or it can also be determined by the parties in the marriage agreement made by the married couple. While Article 29 paragraph (3) of the Marriage Law regulates that marriage agreements come into force from the time marriage is concluded. Furthermore, related to Article 29 Paragraph (4) of the Marriage Law, the Constitutional Court ruling explained that during a marriage, the marriage agreement can be regarding marriage assets or other agreements, can be changed or revoked based on the agreement as long as it does not harm other parties.

The legal consequences of a marriage agreement made after the marriage will certainly be different due to the law if the marriage agreement is made before the marriage takes place. Indonesian citizens who enter into a mixed marriage and do not enter into a marriage agreement, the Indonesian citizen may not have immovable property with ownership or building rights.

Conversely, if a citizen who enters into a mixed marriage makes a marriage agreement before or during the marriage, the citizen can have ownership rights or HGB, because there is no mixing of assets in the marriage. Marriage agreement based on MK Decision Number 69 / PUU-XII / 2015, which determines the permissibility to make a marriage agreement after the marriage takes place or during the marriage, then the separation of assets can occur when the marriage agreement is made and becomes the property of each or at the time the marriage is held (allowed according to the wishes of husband and wife as outlined in the marriage agreement). So that citizens of mixed marriages can have ownership rights or usage rights of building on land. However, if examined in more depth is not simple. Therefore it is necessary to have a deeper understanding of the separation of assets at the time the marriage agreement was made, after the Constitutional Court Decision Number 69 / PUU-XII / 2015 at least gives concessions to a husband and wife to arrange his property in a marriage agreement throughout his marriage, so that changes occur related to making marriage agreements.

The two types of assets will be difficult to distinguish as for example the case of Ike, a judicial review applicant because his household life now has two types of assets, some are shared assets and some are separate assets. What if their marriage broke up, either because of divorce or because of death. In the event of a divorce the parties can divide it according to the position of the asset, if the property is a separate asset after the marriage agreement is made after the marriage takes place, the asset will become the property of each party. However, if the property is shared property, the shared property is shared between the husband and wife parties. This husband and wife first agreed to become joint property before the marriage agreement was made.

It would be different if their divorce broke up due to a death, then the division would also be distinguished between shared property and separate property. Shared assets are divided into two, namely for the living and the deceased who are inheritance, while the separate assets will become inheritance, so that the shared assets of the deceased and the separated assets of the deceased will become one inheritance. The distribution of inheritance does not rule out the possibility of a mixed marriage couple 
gave birth to offspring who have not yet become Indonesian citizens. Although the distribution of inheritance is done according to the law of the testator. If the inheritance is an immovable object, while the heirs are foreign, then the results of the study of immovable property must not be directly divided into immovable objects, but must be sold first, then divided into money.

Therefore the Constitutional Court Decision Number 69 / PUU-XIII / 2015 concerning Marriage Agreement requires a very careful and wise implementation, and according to Sari Murti (2017) it is required that the implementation of the making of the marriage agreement must be done in good faith. Although the ruling of the Constitutional Court is an effort to reform the law that guarantees the constitutional rights of Indonesian citizens who engage in mixed marriages related to the regulation of their property in marriage.

It should also be understood that the issuance of Constitutional Court Decision Number 69 / PUU-XIII / 2015 on the petition for judicial review for mixed marriages which at the time of marriage did not make a marriage agreement. Article 21 Paragraph (1) and Article 36 Paragraph (1) of the BAL are based on the principle of nationality that foreigners cannot control property rights and HGB on land (immovable objects). So according to the opinion of the writers of the Constitutional Court Decision Number 69 / PUU-XIII / 2015, it should be interpreted that the conduct is only for mixed marriages for whom marriages have not yet been entered into / without marriage agreements.

Provisions relating to the consequences of marital law over assets in the Marriage Law cannot be denied that the civil aspects are more stand out compared to the provisions in the Civil Code. The author believes that because the mastery of marital property obtained before marriage is classified as inherited property and remains controlled by each party. Doesn't this mean that there is an affirmation of respect for personal property which is then unconsciously in addition to being sacred and religious, the civil aspect also stands out. While based on the provisions in the Civil Code which views marriage in civil aspects, it does not explicitly acknowledge the existence of personal property obtained before marriage because as long as no marriage vows are made for the separation of assets, all husband and wife assets are united into the unity of the marriage since the marriage takes place (Article 119 of the Civil Code).

For this reason, the Constitutional Court's decision was hurriedly judged as a decision that seemed to only see the marriage institution as a contractual relationship simply because the provisions regarding the marriage agreement were not actually intended to regulate all matters relating to the legal consequences of a marriage so as to allow contract marriage through a marriage agreement. Only the matter of assets is possible to be regulated by a marriage agreement because the provisions in the Marriage Law are for the most part a dwingend recht.

To answer the problem as stated earlier, the author is of the opinion that the provisions governing the legal consequences of marriages on marital property, in the provision of Article 35 paragraph (1) it is said that the assets obtained during marriage become joint property. For this reason, if the parties want a separation of assets in the marriage, then both parties with mutual agreement can enter into a written agreement that is ratified by the Marriage Registrar (Article 29 paragraph (1)).

Based on the provisions of Article 29 paragraph (1), it is actually intended to be emphasized that the agreement needs to be recorded by the Registrar of Marriage to fulfill the principles of inheritance so that the agreement regarding property in the marriage will also be binding on third parties. Thus the phrase "ratified by Marriage Registrar" in that article is not intended as a determinant of the validity of a marriage agreement because the criteria for determining the validity of a marriage agreement can be found in Article 29 paragraph (2) saying that the agreement cannot be ratified if it violates the boundaries law, religion and decency.

Based on this understanding, the marriage agreement made especially after the marriage takes place in addition to the provisions of Article 29 paragraph (1) in order to fulfill the principle of publicity 
and provisions of paragraph (2) so that the contents of the marriage agreement do not violate legal, religious and moral boundaries. The legal boundaries referred to certainly refer to the law that is compelling (dwingend recht), among others as stipulated in Article 21 paragraph (1) and Article 36 paragraph (1) of the UUPA formulated based on the principle of nationality, that foreigners cannot have property rights and $\mathrm{HGB}$ on land. On that basis, these provisions cannot be declared contrary to the Constitution.

\section{Conclusions}

a. The importance of the marriage agreement related to joint property states that it is important that the marriage agreement is related to the position of joint property so that there is a separation of husband's assets from the wife's assets, both in regard to their respective belongings and assets acquired during the marriage known as joint assets. Whereas the assets obtained before their marriage period together are known as property or personal property obtained after the marriage period which is usually referred to as acquisition. With the marriage agreement to the joint assets obtained a legal certainty of the status of husband / wife assets so that if a divorce occurs, both death / divorce of life, the distribution of these assets does not take a long time because the status of their assets has been previously agreed in marriage agreement.

b. Legal consequences for marital property before and after MK Decision Number 69 / PUU-XIII / 2015 concerning marital agreements that the position of marital property before the Constitutional Court ruling Number 69 / PUU-XIII / 2015 that if the marriage is not made a marriage agreement that regulates Regarding assets obtained during the marriage period, assets obtained during the marriage period become joint property (gono gini), but if a husband and wife make a marriage agreement governing his property, then based on article 29 of the Marriage Law that a marriage agreement must be made before or during the marriage takes place, the marriage agreement cannot be changed unless between the two parties there is an agreement to change and the change does not harm a third party. Then after the issuance of the Constitutional Court's ruling, the provisions of Article 29 paragraph (1) of the Marriage Law in conjunction with the ruling of the Constitutional Court Number 69 / PUU-XIII / 2015, that marriage agreements other than can be made before or at the time of marriage, can also be made after or during the bond. marriage, with mutual agreement, a marriage agreement can be submitted in writing that is ratified by the marriage registrar. Whereas the legal consequences for marriages are mixed marriage agreements made after the marriage will certainly have different legal consequences if the marriage agreement was made before the marriage took place. In simple terms due to the legal marriage agreement before the Constitutional Court Decision Number 69 / PUU-XII / 2015, Indonesian citizens who enter into a mixed marriage and do not make a marriage agreement, the Indonesian citizen cannot have immovable objects with ownership or building rights. Conversely, if a citizen who enters into a mixed marriage makes a marriage agreement before or during the marriage, the Indonesian citizen can have ownership rights or HGB. 


\section{References}

A. Books

Abdul Rasyid Thalib, 2006, Wewenang Mahkamah Konsitusi dan Impilkasinya dalam Sistim Ketatanegaraan Republik Indonesia. Citra Aditya Bakti: Bandung.

Achmad Ali. 2002, Menguak Tabir Hukum (Suatu Kajian Filosofis dan Sosiologis), Jakarta:Toko Gunung Agung.

Ahmad Rofiq, 1997, “Hukum Islam Di Indonesia”, Jakarta: PT. Raja Grafindo Persada.

Agus Susanto, 2012, Hukum, Moral dan Keadilan Sebuah Kajian Filsafat Hukum, Jakarta: Kencana Prenada Media Group.

Ali Afandi, 1997, “Hukum Waris, Hukum Keluarga Dan Hukum Pembuktian”,Jakarta: PT. Rineka Cipta. Suryono Sukanto \& Sri Mamuji, 2012, Penelitian Hukum Normatif, cet. empat balas, Jakarta: PT. Raja Grafindo Persada.

Surayin, 2001, Kamus Umum Bahasa Indonesia, Analisis, Yrama Widya, Bandung,.

Tutik Triwulan, 2010. Konstruksi Hukum Tata Negara Indonesia Pasca Amandemen UUD 1945. Kencana: Jakarta.

Titik Triwulan, 2011, Hukum Perdata Dalam Sistem Hukum Nasional, Kencana Prenada Media Grup, Jakarta.

Wirjono Prodjodikoro, 1974, Hukum Perkawinan Di Indonesia, Sumur Bandung, Bandung.

Wirjono Projodikoro, 1981, Hukum Perdata Tentang Persetujuan-Persetujuan Tertentu, Bandung: Sumur.

Zainal Arifin Hoesein. 2009. Judical Review di Mahkamah Agung RI, Tiga Dekade Pengujian Peraturan Perundang-undang. Raja Grafindo Persada: Jakarta.

B. Legislation

KUHPer (Kitab Undang-Undang Hukum Perdata)

Consideration of judicial review of the constitutional court material on the MK Decision Number: 46/PUU-XIII/2015

Putusan Mahkamah Konsitusi Nomor 69/PUU-XIII/2015 Tentang Perjanjian Perkawinan

Republik Indonesia, Undang-Undang Dasar 1945, Bab I, Pasal 1 Ayat (3)

Undang-Undang Nomor 1 tahun 1974 Tentang Perkawinan

Undang-Undang Nomor 5 tahun 1960 tentang Peraturan Dasar Pokok-Pokok Agraria 


\section{Website and Blog}

Avivsyuda. 2012. Mahkamah Konstitusi. Di Akses dari:

http://avivsyuhada.wordpress.com/2012/06/23/mahkamah-konstitusi/. [30 Agustus 2013]

Sriono, Perjanjian Kawin Sebagai Bentuk Perlindungan Terhadap Harta Kekayaan Dalam Perkawinan, Jurnal Ilmiah Advokasi, Volume 4 Nomor 2, September 2016

Dwika, “Keadilan dari Dimensi Sistem Hukum”, (02/04/2011), diakses pada 24 Juli 2017.

Informasi Media, Pengertian Definisi Analisis, diakses dari: http//media informasil.com/2012/04/pengertian-definisi-analisis.htm,padatanggal 17 Agustus 2017,pukul 17.00 WIB

Jimly Asshiddiqie, www.jimly.com/makalah/HAK_KONSTITUSIONAL PEREMPUAN.doc, downloaded 09 April 2017.

Jurnal dunia-ibu.org online, Perjanjian Pranikah, copyright 2001-2002 dalam http://www.duniaibu.org/ html/ perjanjian_pra_nikah.html), diaksespada 2 April 2018.

Nabila Afinannisa, 27 Desember 2012, Penegak hukum, Kesadaran Hukum, dan Pelaksanaan Hukum(online),http://vinabilla.blogsport.com/2012/12penegakan-hukum-kesadaran-hukumdan.html, diakses21 juli 2017

Rina Anggraini, tanpa tahun, "Pernikahan Agama Hindu”, URL http://www.academia.edu/6498041/Pernikahan-Agama-Hindu, diakses 22 Juli 2017

Sulistianing Astuti.2010. Popularitas dan Eksistensi Mahkamah Konstitusi. Di aksesdari:http://lingkarstudihukumperkembangansosial.blogspot.com/2008/11/popularitas-dan eksistensi-mahkamah.html. [1 September 2017].

www.lindungikami.org/.../UU_Nomor_39_tentang_Hak_Asasi_Manusia.pdf

\section{Copyrights}

Copyright for this article is retained by the author(s), with first publication rights granted to the journal.

This is an open-access article distributed under the terms and conditions of the Creative Commons Attribution license (http://creativecommons.org/licenses/by/4.0/). 